\title{
Mourning dove densities on Chihuahuan Desert rangelands
}

\author{
JAMUS JOSEPH, JERRY L. HOLECHEK, RAUL VALDEZ, AND MILT THOMAS
}

Authors are former Graduate Student andProfessor, Department of Animal and Range Sciences, New Mexico State University, Las Cruces, N.M. 88003; Professor, Department of Fishery and Wildlife Sciences, New Mexico State University, Las Cruces, N.M .88003; and Assistant Professor, Department of Animal and Range Sciences, New Mexico State University, Las Cruces, N.M. 88003.

Abstract

Mourning dove (Zenaida macroura $\mathrm{L}$.) densities were determined using strip census techniques over a 2-year period (spring 1996 to winter 1998) on pastures in early-, mid-, and late-seral ecological condition. This study was conducted on the Chihuahuan Desert Rangeland Research Center and adjacent Bureau of Land Management rangelands in south-central New Mexico on 6 adjoining pastures that were similar in terrain and shape. Mourning dove densities pooled across sampling periods (8) were different $(\mathrm{P}<0.10)$ on pastures in mid- and early-seral condition. They averaged $10.3,33.9$, and 7.2 birds $\mathrm{km}^{-2}$ on pastures in late-, mid- and early-seral condition, respectively. Leatherleaf croton (Croton pottsii Lam.), the primary mourning dove food on all study pastures, was more abundant $(\mathrm{P}<0.10)$ on late- and mid-seral pastures than on early-seral pastures. Therefore, heavy livestock grazing may adversely affect mourning dove populations in the Chihuahuan Desert by depleting leatherleaf croton. Autumn perennial grass cover and standing biomass differed $(\mathrm{P}<0.10)$ among seral stages. More optimal interspersion of bare ground and perennial grasses may further explain why mid-seral rangelands tend to favor mourning doves. Our study shows mourning doves in the Chihuahuan Desert prefer moderately grazed, mid-seral rangelands over heavily grazed, early-seral rangelands.

Key Words: upland game bird, wildlife, arid lands, cattle grazing, Zenaida macroura

Mourning doves (Zenaida macroura L.) occur on rangelands throughout New Mexico. They are the most important upland game bird in this state based on annual hunter harvest data collected by the New Mexico Game and Fish Department. Populations of mourning doves in New Mexico vary among years, but showed a tendency to decline from 1989-98 (Dolton and Smith 1998). Better information on mourning dove habitat requirements would allow managers on public and private lands to maintain and/or possibly increase populations. Ecological condition can influence mourning dove use of upland Chihuahuan Desert rangelands. Recent research indicates mourning doves prefer late-seral over climax Chihuahuan Desert rangelands
Las densidades de "Mourning dove" (Zenaida macroura $\mathbf{L}$.) fueron determinadas en potreros de condición ecológica es estado seral inicial, medio y final durante un período de dos años (primavera de 1996 e invierno de 1998) y para ello se usaron técnicas de censo en bandas. El estudio se condujo en el Centro de Investigación de Pastizales del Desierto Chihuahuense y 6 potreros adjuntos que eran similares en el terreno situados en pastizales adjuntos propiedad del Buró de Manejo de Tierras en la region sur-centro de Nuevo Mexico. Las densidades de "Mourning dove" conjuntadas a través de los períodos de muestreo $(8)$ fueron diferentes $(P<0.10)$ en los potreros de condición ecológica de estado seral medio e inicial, ellas promediaron $10.3,33.9$ y 7.2 aves $\mathrm{km}-2$ en los potreros de condición de estado seral final, medio e inicial respectivamente. El "Leatherleaf croton" (Croton pottsii Lam.), el principal alimento del "Mourning dove" en todos los potreros de estudio, fue más abundante $(\mathbf{P}<\mathbf{0 . 1 0})$ en los potreros de estado seral final y medio que en los de estado seral inicial. Por lo tanto, el apacentamiento fuerte del ganado puede afectar adversamente las poblaciones de "Mourning dove" en el Desierto Chihuahuense al agotar el "Leatherleaf croton". La cobertura de zacates perennes en otoño y la biomasa en pie difirió $(P<0.10)$ entre los estados serales. El entremezclado más óptimo de áreas de suelo desnudo y zacates perennes puede explicar má porque los estados serales medios y final tienden a favorecer al "Mourning dove". Nuestro estudio muestra que el "Mourning dove" del Desierto Chihuahuense prefiere pastizales de estado seral medio moderadamente apacentados sobre los pastizales de estado seral inicial fuertemente apacentados

(Smith et al. 1996). However, Nelson et al. (1997) and Saiwana et al. (2001) discovered that mourning dove use did not differ between late- and mid-seral Chihuahuan Desert rangelands. Mourning dove use of early-seral rangelands has not been evaluated. Our objective was to determine mourning dove densities on late-, mid-, and early-seral pastures in the Chihuahuan Desert of south-central New Mexico, and to explain factors responsible for observed patterns. 


\section{Materials and Methods}

\section{Study Area}

We conducted our study on the Chihuahuan Desert Rangeland Research Center (CDRRC) and adjacent Bureau of Land Management (BLM) rangelands in Doña Ana County, N.M. 37 km north of Las Cruces (22 $\left.32^{\prime} 30^{\prime \prime} \mathrm{N}, 106^{\circ} 52^{\prime} 30^{\prime \prime} \mathrm{W}\right)$. The CDRRC and BLM study areas are each about 10,000 ha in size. Elevation of the study area varies from 1,330 to 1,348 m above sea level (Wood 1969, Valentine 1970).

The area is arid, with no permanent water except for stock watering points supplied by wells and earthen tanks. About half the annual precipitation occurs between July and September; highest precipitation occurs in August. Wood (1969) described the climate of the area as semidesert with temperatures varying from $-23^{\circ}$ (Jan) to $42^{\circ} \mathrm{C}$ (Jun). Extreme daily fluctuations of $30^{\circ} \mathrm{C}$ can occur. Annual precipitation on the study area in 1996 and 1997 was 200 and $312 \mathrm{~mm}$, respectively. These totals are 84 and $132 \%$ of the longterm (70 years) average $(236 \mathrm{~mm})$. Growing season (July, August, September) precipitation amounts in 1996 and 1997 were 130 and $151 \mathrm{~mm}$, respectively. These are 104 and $151 \%$, respectively, of the 70 year average $(125 \mathrm{~mm})$. Prior to the 1994-1996 period, several years of above average precipitation had occurred on the study area (Molinar 1999).

Soils of the CDRRC and BLM study areas consist mainly of light sandy loams underlain by calcium carbonate hardpan (caliche) at depths varying from a few centimeters to greater than $1 \mathrm{~m}$ (Valentine 1970, Holechek et al. 1994). Soils are classified as fine loamy, mixed thermic, typic haplargids in the Simona-Cruces association (Soil Conservation Service 1980). In areas where the ground cover is sparse, sandy dunes have formed around invading honey mesquite plants (Prosopis glandulosa Torr., Wood 1969).

Holechek et al. (1994) characterized the study area vegetation as Chihuahuan Desert grassland with scattered shrubs. Honey mesquite dominates large portions of the BLM lands, probably because of overgrazing by livestock and periodic droughts (Paulsen and Ares 1962, Buffington and Herbel 1965). Vegetation on the CDRRC consisted largely of black grama (Bouteloua eriopoda Torr.), mesa dropseed (Sporobolus flexuosus Thurb.), and spike dropseed (S. contractus Hitch.). Broom snakeweed (Gutierrezia sarothrae Pursh.) dominated a few small, early-seral areas. Leatherleaf croton (Croton pottsii Lam.) is the principal perennial forb found on the study area and is a primary food of mourning doves (Davis and Anderson 1973). A detailed description of CDRRC vegetation is provided by Wood (1969), and a discussion of desert grassland vegetation is provided by Pieper and Herbel (1982).

\section{Pastures}

In 1995 , we selected 4 pastures on the Chihuahuan Desert Rangeland Research Center (CDRRC) and 2 pastures on adjoining land controlled by the BLM for our study. These 6 pastures had similar soils (sandy loams), topography (flat), and water availability. Pasture sizes ranged from 932 to 2,050 ha. When we started our study in 1996, 2 pastures on the CDRRC were in late-seral ecological condition (57 and $64 \%$ of climax vegetation) and 2 pastures were in mid-seral ecological condition (32 and $37 \%$ of climax) (Molinar 1999), using the quantitative climax approach of Dyksterhuis (1949). We classified the 2 BLM study pastures on the northern boundary of the CDRRC as in early-seral ecological condition (10 and $14 \%$ remaining climax vegetation). From 1988 to 1998 , the late-seral pastures received light to conservative cattle grazing ( 25 to $35 \%$ use of forage), the 2 midseral pastures were moderately grazed (40 to $49 \%$ use), and the early-seral pastures were heavily grazed ( 50 to $60 \%$ use) based on various surveys (Tembo 1990, Holechek et al. 1994, Joseph 2002). Grazing on all 6 study pastures was yearlong from the 1930 s to present with the exception of severe drought periods when complete destocking was sometimes required. Cattle were removed from the mid-seral and late-seral pastures from August 1994 to April 1997. Partial restocking was done in April 1997 and full stocking was done in November 1997 to obtain $30 \%$ use on late-seral pastures and $40 \%$ use on mid-seral pastures.

\section{Mourning Dove Counts}

We divided each study pasture into 5 near equal divisions. We used a strip census technique (Emlen 1977, Mikol et al. 1979, Anderson et al. 1979) with 1 randomly located transect $(100 \mathrm{~m} \times 1.6 \mathrm{~km})$ within each pasture division (5 transects/pasture) to count mourning doves. These transects were randomly selected using numbered fence posts and power line poles that occurred within each division. With some exceptions, we placed transects $1 \mathrm{~km}$ from boundary fences to minimize ecotone effects where pastures adjoined. All transects were separated by at least $0.8 \mathrm{~km}$. We laid out all transects in straight lines and clearly marked them with wooden stakes and bright plastic flagging ribbons affixed to the branches of shrubs.

We counted mourning doves once per season on each pasture from spring 1996 through winter 1998. Counting was done in the second half of each season between the hours of 0700 and 1100 . Counts during each season were conducted over a 30 day period. Windy and rainy days, extreme heat, and personal needs of the observers explain why the counts were conducted over a 30 day period. Autumn counts were conducted from 5 November to 3 December, winter counts from 5 February to 6 March, spring counts from 5 May to 3 June, and summer counts from 28 July to 30 August. Two observers with college classes and field experience in wildlife population sampling techniques walked transects. Each observer was limited to 2 transects per day. Observers rotated between ecological condition classes within days and among days to avoid confounding biases that may result from survey techniques of individual observers. Mourning doves that were observed in flight but not flushed were omitted from counts, as were those that were heard but not seen. Another potential problem that can occur with the technique is that some birds previously counted can move ahead of the observer and potentially be counted again. The relatively flat, sparse nature of the terrain, and the low level of mourning dove encounters relative to distance traveled, minimized this problem. We considered this source of error to be evenly distributed among transects and pastures. White-winged doves (Zenaida asiatica L.) also occur on the study area, but we did not include these rare encounters in our analyses. We converted counts to mourning dove density (\# $\mathrm{km}^{-2}$ ) for statistical evaluation.

\section{Vegetation Inventory}

We collected foliar cover data during autumn 1998 at 10 key areas spaced evenly across mid-and late-seral pastures (Joseph 2002). We estimated percentage foliar cover on each key area on 2, 61-m transects using a modification of the lineintercept procedure of Canfield (1941) (a meter stick was used on an extended line). We made measurements approximately every $6.1 \mathrm{~m}$ along the transects at each key area. We placed the meter stick perpendicular to the transect and measured the intercept of the plants according to Bonham 
(1989). We estimated standing crop biomass in 1996, 1997, and 1998 on areas separate from dove counts. Autumn standing forage biomass was determined by clipping $20,0.5-\mathrm{m}^{2}$ quadrats at $10-\mathrm{m}$ intervals along 2, 100-m lines on each key area. Vegetation was hand separated by species in the field, oven dried at $60^{\circ} \mathrm{C}$ for 72 hours, and weighed.

On the 2 early-seral pastures, we collected foliar cover and standing biomass data along 5, 800-m transects. These transects were in the center of the $5,1.6-\mathrm{km}$ transects used to count mourning doves, and parallel to them. In autumn 1998, we used the same micro-line procedure used on mid- and lateseral pastures to quantify foliar cover at 100 -m intervals on each transect (40 microlines per pasture). We evaluated autumn forage standing crop in 1996, 1997, and 1998 using the same procedures previously described. At 100 -m intervals along each 800 -m transect, we clipped a $0.5 \mathrm{~m}^{2}$ quadrat (40 quadrats per pasture).

We evaluated grazing intensity on the 6 study pastures at the end of the forage cycle in June of 1997 and 1998 using procedures of Anderson and Currier (1973) as modified by Holechek and Galt (2000). These procedures involved assessing grazing intensity on each study pasture through a combination of perennial grass stubble heights and ungrazed biomass of forage plants. We selected 4 permanent key areas within each pasture for these assessments. We selected these key areas by dividing each pasture into 4 equal parts and then locating the key area near the center of each part. All key areas were 1.3 to $1.8 \mathrm{~km}$ from water.

\section{Statistical Analysis}

We used a repeated measures analysis of variance with the mixed model procedure of SAS (Littell et al. 1996) to compare mourning dove densities across rangeland ecological condition classes (3), seasons (4), and years (2). Pastures (2/condition class) were used as experimental units with transects within pastures (5/pasture) considered to be sub-samples. We used this same type of analysis to compare standing biomass and foliar cover among rangeland ecological condition classes and years. The $10 \%$ probability level was used in all statistical tests.

\section{Results}

Mourning dove densities differed among ecological condition classes and seasons, but not between years (Tables 1 and 2).
On late-, mid-, and early-seral pastures, mourning dove densities averaged 10.3, 33.9 , and 7.2 birds $\mathrm{km}^{-2}$, respectively, when data were pooled across seasons and years. Pastures in mid-seral condition had higher dove densities than those in earlyseral condition. In spring and summer, dove densities were higher than in autumn and winter. The interaction between ecological condition classes, seasons, and years was not significant. We observed a total of 1,325 mourning doves.

and least on early-seral pastures (Table 1). Black grama, the primary perennial forage grass in the Chihuahuan Desert (Paulsen and Ares 1962), had greatest standing biomass in late-seral pastures (Table 1). Black grama was rarely encountered on the early-seral pastures, but was the primary perennial grass on both mid- and lateseral pastures (Table 1). Leatherleaf croton had lower standing biomass on earlyseral than mid- and late-seral pastures (Table 1).

Table 1. Mourning dove density and vegetation characteristics associated with years and pastures in early-, mid-, and late-seral ecological condition on Chihuahuan Desert rangelands in southcentral New Mexico.

\begin{tabular}{|c|c|c|c|c|c|c|}
\hline \multirow[b]{2}{*}{ Characteristic } & \multicolumn{3}{|c|}{ Year } & \multicolumn{3}{|c|}{ Seral Stage } \\
\hline & 1996 & 1997 & 1998 & Early & Mid & Late \\
\hline \multirow[t]{2}{*}{ Mourning Dove Density } & \multicolumn{6}{|c|}{ 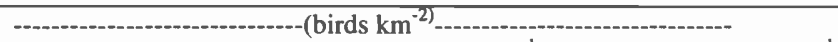 } \\
\hline & $15.3^{\mathrm{a}}$ & $18.9^{\mathrm{a}}$ & - & $7.2^{b}$ & $33.9^{\mathrm{a}}$ & $10.3^{\mathrm{ab}}$ \\
\hline Cover & $-\cdots$ & & $--(\%)-$ & - & (n) & \\
\hline Total & - & - & 6.9 & $13.5^{\mathrm{a}}$ & $3.7^{\mathrm{b}}$ & $3.7^{\mathrm{b}}$ \\
\hline Perennial grass & - & - & 0.7 & $t^{c}$ & $0.7^{b}$ & $1.3^{\mathrm{a}}$ \\
\hline Forb & - & - & 0.5 & $0.7^{\mathrm{a}}$ & $0.5^{\mathrm{a}}$ & $0.3^{\mathrm{a}}$ \\
\hline Shrub & - & - & 5.7 & $12.8^{\mathrm{a}}$ & $2.4^{\mathrm{b}}$ & $2.0^{b}$ \\
\hline \multicolumn{2}{|l|}{ Bouteloua eriopoda } & - & 0.4 & $\mathrm{t}^{\mathrm{b}}$ & $0.5^{\mathrm{a}}$ & $0.7^{\mathrm{a}}$ \\
\hline \multicolumn{7}{|l|}{ Autumn Standing Biomass } \\
\hline \multicolumn{7}{|l|}{-} \\
\hline Total & $147.2^{b}$ & $351.8^{\mathrm{a}}$ & $306.9^{a}$ & $117.7^{c}$ & $351.5^{b}$ & $416.1^{\mathrm{a}}$ \\
\hline Perennial grass & $62.8^{b}$ & $150.2^{\mathrm{a}}$ & $138.9^{a}$ & $9.3^{c}$ & $165.9^{b}$ & $225.0^{\mathrm{a}}$ \\
\hline Bouteloua eriopoda & $38.3^{b}$ & $77.0^{\mathrm{a}}$ & $89.2^{a}$ & $0.3^{c}$ & $83.0^{b}$ & $140.4^{a}$ \\
\hline Croton pottsii & $13.2^{b}$ & $31.7^{\mathrm{a}}$ & $36.6^{\mathrm{a}}$ & $0.7^{b}$ & $50.5^{a}$ & $36.9^{\mathrm{a}}$ \\
\hline
\end{tabular}

$\overline{a, b, c}$ Means with different letters within each main effect differ $(P<0.10)$.
Total vegetation and total perennial grass cover in autumn differed among ecological condition classes (Table 1). Perennial grass cover was least on the early-seral and greatest on the late-seral class (Table 1). Shrub cover (primarily honey mesquite) was greatest on the earlyseral class and similar on mid-and lateseral classes. Total forb cover did not differ among ecological condition classes.

Total autumn standing biomass of perennial grasses was greatest on late-seral
Forage use levels in June 1997 on late-, mid-, and early-seral pastures were estimated to be 10,18 and $67 \%$, respectively. Based on various stocking rate studies, Holechek et al. (1999) classified forage use levels of $0-30 \%$ as light, $31-40 \%$ as conservative, $41-50 \%$ as moderate, and > $50 \%$ as heavy. Light use levels occurred on the late- and mid-seral pastures because they were rested in 1996, partially stocked in April 1997, and then fully stocked in November 1997. In late June 1998, forage
Table 2. Mourning dove densities on pastures in early-, mid-, and late-seral ecological condition in the spring, summer, autumn, and winter of 1996-97 and 1997-98.

\begin{tabular}{|c|c|c|c|c|}
\hline Seral Stage & Spring & Summer & Autumn & Winter \\
\hline & ----- & $--(b$ & - & -.-- \\
\hline \multicolumn{5}{|l|}{$1996-97$} \\
\hline Early & 4.4 & 0.7 & 0 & 0 \\
\hline Mid & 130.4 & 9.8 & 0 & 0 \\
\hline Late & 9.8 & 16.6 & 0 & 12.6 \\
\hline \multicolumn{5}{|l|}{$1997-98$} \\
\hline Early & 50.0 & 2.5 & 0 & 0 \\
\hline Mid & 8.8 & 120.9 & 0.6 & 0.6 \\
\hline Late & 4.6 & 39.2 & 0 & 0 \\
\hline$\overline{\mathbf{x}}$ & $34.6^{\mathrm{a}}$ & $31.6^{b}$ & $0.1^{b}$ & $2.2^{\mathrm{b}}$ \\
\hline
\end{tabular}

${ }^{\mathrm{a}, \mathrm{b}}$ Means with different letters within each main effect differ $(\mathrm{P}<0.10)$. 
use levels were estimated to be 33 (conservative), 45 (moderate), and $61 \%$ (heavy) on late-, mid-, and early-seral pastures, respectively.

\section{Discussion}

Large areas of rangeland surrounded all our study pastures. This minimized the effects of outside influences such as dams, roads, trees, urban areas, and agricultural lands that could have caused doves to use particular pastures differently than others. Therefore, mourning dove density should be related to differences in ecological condition among pastures.

Mourning doves have certain basic needs for food, water, and cover (Sadler 1993) which were influenced by the grazing history and subsequent ecological condition of the pastures we studied. The midseral pastures provided a better optimization of food and cover than those in earlyseral condition. We believe that availability of dove foods, particularly leatherleaf croton (Davis and Anderson 1973), could explain in part why mourning dove densities were higher on mid- than early-seral pastures. Croton was nearly absent from the early-seral pastures, but was prevalent throughout the mid-seral pastures.

Although not different statistically, mourning dove densities were over 3 fold higher on mid- than late-seral pastures. This could be related to differences in perennial grass cover and biomass between mid- and late-seral pastures. Both perennial grass cover and biomass were higher on late-seral than on mid-seral pastures. Mourning doves were commonly observed in areas with a high component of mesa dropseed and scattered shrubs. This type of habitat was most prevalent on the mid-seral pastures. Unlike black grama which is stoloniferous and grows in dense stands, mesa dropseed is a bunchgrass with considerable bare ground occurring around individual plants. Mourning doves were seldom encountered in large, dense stands of black grama which were more common on late-seral pastures. Mourning doves avoid areas with a dense perennial grass cover for nesting and feeding (Soutiere and Bolen 1976, Bock et al. 1984, Baker and Guthery 1990).

Honey mesquite, an important nesting substrate for mourning doves (Soutiere and Bolen 1976), covered 8.9, 1.9, and $1.7 \%$, on early-, mid-, and late-seral pastures. However, we doubt that honey mesquite cover was an important influence on results from our study. Honey mesquite plants were evenly distributed and prevalent throughout all 6 study pastures. On climax Chihuahuan Desert grassland, where honey mesquite and other shrubs are nearly absent in the vegetation composition, mourning dove density is low. For example, Smith et al. (1996) documented fewer mourning doves on climax Chihuahuan Desert grassland without mesquite than on late-seral rangelands with scattered honey mesquite plants (1.6 versus 22.3 doves $\mathrm{km}^{-2}$, respectively).

Our data suggest that mourning doves in the Chihuahuan Desert prefer mid-seral areas moderately grazed by cattle over early-seral, heavily grazed areas. Earlier mourning dove studies on the CDRRC have also shown that dove density did not differ on pastures with 32 to $67 \%$ remaining climax vegetation under conservative or moderate cattle grazing (Nelson et al. 1997, Saiwana et al. 2001). However, seral stage does influence habitat selection by mourning doves in the Chihuahuan Desert. Smith et al. (1996) found a lightly grazed Chihuahuan Desert rangeland in climax condition (86\% remaining climax vegetation) had lower mourning dove densities than a conservatively grazed, lateseral rangeland $(72 \%$ remaining climax vegetation).

Seasonal differences we encountered in mourning dove densities can be explained. Low mourning dove density on all pastures in autumn and winter is attributed to the fact they are migratory and vacate the area with the onset of cooler temperatures in October. When temperatures become warm in March and April, they begin moving back into the area. This observation was also reported by Nelson et al. (1997).

\section{Management Implications}

In the Chihuahuan Desert, heavy cattle grazing can adversely impact mourning dove habitat by reducing availability of important foods, such as leatherleaf croton. In contrast, moderate or conservative cattle grazing provides suitable mourning dove habitat. Application of conservative and moderate grazing intensities over time will minimize the proportion of land in an early stage and maximize the proportions of land in mid- and late-seral stages. This should maximize diversity in vegetation composition and structure and provide high quality mourning dove habitat.

\section{Literature Cited}

Anderson, D. R., J. L. Lzake, B. R. Crain, and K. P. Burham. 1979. Guidelines for line transect sampling of biological populations. J. Wildl. Manage. 43:70-78.

Anderson, E. W. and W. F. Currier. 1973. Evaluating zones of utilization. J. Range Manage. 26:87-91.

Bock, C. E., J. H. Bock, W. R. Kenney, and V. M. Hawthorne. 1984. Response of birds, rodents, and vegetation to livestock exclosures in a semidesert grassland site. J. Range Manage. 37:239-242.

Baker, D. L. and F. S. Guthery. 1990. Effects of continuous grazing on habitat and density of ground-foraging birds in south Texas. J. Range Manage. 43:2-5.

Bonham, C. D. 1989. Measurements for terrestrial vegetation. John Wiley and Sons, New York, N.Y.

Buffington, L. C. and C. H. Herbel. 1965. Vegetation changes on semi-desert grassland range from 1858 to 1963 . Ecol. Monogr. 35:139-164.

Canfield, R. H. 1941. Application of the line intercept method in sampling range vegetation. J. Forest. 39:388-394.

Davis, C. A. and M. W. Anderson. 1973. Seasonal food use by mourning doves in the Mesilla Valley, south-central New Mexico. New Mexico Agr. Exp. Sta. Bull. 612.

Dolton, D. D. and G. W. Smith. 1998. Mourning dove breeding population status, 1998. U.S. Fish and Wild. Serv. Washington, D.C.

Dyksterhuis, E. J. 1949. Condition and management of rangeland based on quantitative ecology. J. Range Manage. 2:104-115.

Emlen, J. T. 1977. Estimating densities of birds derived from transect counts. Auk 95:455-468.

Holechek, J. L. and D. Galt. 2000. Grazing intensity guidelines. Rangelands 22 (3):11-14.

Holechek, J. L., H. Gomez, F. Molinar, and D. Galt. 1999. Grazing studies: What we've learned. Rangelands 21 (2): 12-16.

Holechek, J. L., A. Tembo, A. Daniel, M. Fusco, and M. Cardenas. 1994. Long-term grazing influences on Chihuahuan Desert rangeland. Southw. Nat. 39:342-349.

Joseph, J. 2002. Effects of rangeland ecological condition on wildlife habitat use in the Chihuahuan Desert. Ph.D. Thesis, New Mexico State Univ., Las Cruces, N.M.

Littell, R. C., G. A. Milliken, W. W. Stroup, and R. B. Woulfinger. 1996. SAS system for mixed models. SAS Inst., Cary, N.C.

Mikol, S. A., J. J. Hickey, A. K. Stratman, and M. E. Lardy. 1979. Comparison of bird transect estimators in sagebrush and grassland habitats, pp. 1-7. In: Estimating breeding bird densities on coal lands in Montana and Wyoming. U.S. Fish and Wildl. Serv., West. Energy and Land Use Team Report 79/W3. 
Molinar, F. 1999. Effect of honey mesquite cover and soil depth on forage production in the Chihuahuan Desert. Ph.D. Thesis, New Mexico State Univ., Las Cruces, N.M.

Nelson, T., J. L. Holechek, R. Valdez, and M. Cardenas. 1997. Wildlife numbers on lateand mid-seral Chihuahuan Desert rangelands. J. Range Manage. 50:593-599.

Paulsen, H. A., Jr. and F. N. Ares. 1962. Grazing values and management of black grama and tobosa grasslands and associated shrub ranges of the southwest. U.S. Dep. Agr. Tech. Bull. 1270.

Pieper, R. D. and C. H. Herbel. 1982. Herbage dynamics and primary productivity of a desert grassland ecosystem. New Mexico Agr. Exp. Sta. Bull. 695.
Sadler, K. C. 1993. Mourning dove harvest. pp. 449-458. In: T. S. Baskett, M. W. Sayer, R. E. Tomlinson, and R. E. Mirarchi, (eds.) Ecology and Management of the Mourning Dove. Stackpole Books, Harrisburg, Penn.

Saiwana, L., J. L. Holechek, R. Valdez, and M. Cardenas. 2001. Mourning dove numbers on different seral communities in the Chihuahuan Desert. West. North Amer. Nat. 61:50-56.

Smith, G., J. L. Holechek, and M. Cardenas. 1996. Wildlife numbers on excellent and good condition Chihuahuan Desert rangelands: An observation. J. Range Manage. 49:489-493.

Soil Conservation Service. 1980. Soil survey of Dona Ana County, New Mexico. U. S. Dep. Agr. - Soil Cons. Ser.
Soutiere, B. C. and E. G. Bolen. 1976. Mourning dove nesting on tobosa grassmesquite rangeland sprayed with herbicide and burned. J. Range Manage. 29:226-231.

Tembo, A. 1990. Influence of watering and range condition on vegetation of Chihuahuan Desert. Ph.D. Thesis, New Mexico State Univ., Las Cruces, N.M.

Valentine, K. A. 1970. Influence of grazing intensity on improvement of deteriorated black grama range. New Mexico Agr. Exp. Sta. Bull. 553.

Wood, J. E. 1969. Rodent populations and their impact on desert rangelands. New Mexico State Univ. Agr. Exp. Sta. Bull. 555. 